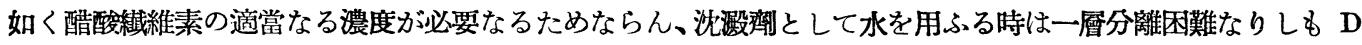
を沈澱する時には最後に水をも用ひたり $\mathrm{C}, \mathrm{D}$ の部分は遠心器を用ひて分別し D は倘分れ難き故に一部低溫 蒸發をも試みたりか〉るものを薄片に押し擴げて（其後の處理に最も好都合なる故に） $30^{\circ} \mathrm{C}$ の扇風乾燥器に て乾し後濃硫酸デシヶーターに貯へて恒量となるまで乾燥したり

酸價は既報 (喜多-etc. 理研、3，13) のクネーベンナーゲル泓 (Ang. 1914, 27, 505)を次の如く少しく變更 して用ふ試料 $0.500 \mathrm{~g}$ をとり $75 \%$ アルコール $25 \mathrm{cc}$ を加へ 50 〜 $60^{\circ} \mathrm{C}$ の浴中に入れて 30 分間加溫す、あるも のは已に溶解し然らざるものも各々膨潤すこれを冷し 25cc の挸定 $\mathrm{NaOH}$ を加へゴム栓にて密栓して一夜放 置す後 $25 \mathrm{cc}$ の規定 $\mathrm{SO}_{4} \mathrm{H}_{2}$ を加へゴム栓を施して振りまはし其儘少時放置し後規定 $\mathrm{NaOH}$ を以フェノール フタレンを指示藥として滴定す（規定液の代りに牛規定液を用ふる方好結果なりき）簡便正確なる方法なりと 信ず

Hess 法による分子量測定は著者の未熟によるか或は此方法に限つて必要なる特殊のデリヶートなる要件 (Hess-Weltzien, Ann. 1926, 450, 29; Hess-Michel, Ber. 1927, 60, 1898; Pummler, Ber. 1929, 62, 2630; Hess-Pichlmayer, Ann, 1926, 450, 29; Freudenberg-Bruch, Ber. 1930, 63, 535; Bergmann-Machemer, Ber. 1930，63，1930）の䉆めか要するに不良なる結果を與へたり

粘度は $1 \%$ アセトン溶液 5cc を用ひ Ostwald 型粘度計 (水, $25^{\circ}$ にて各 22.0 秒 $20.0,18.4$ 秒) により $25^{\circ} \mathrm{C}$ にて測り Centipoise として表はす

（東京帝國大學工學部應用化學科研究室）（昭和五年一一月八日受理）

\title{
コールタール成分の熱分解に關する研究（第七報） メタクレッ゚ールの熱分解反應生成物
}

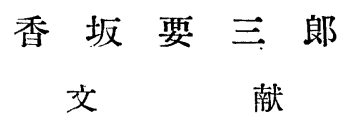

スミス (W. Smith, J. Soc. Chem. Ind., 1890, 9, 447) はクレゾールと水素の混合物を鐵屑を滿たせる赤熱 硝子管に通してトルオール及ベンゾールを得フィッシャー等 (F. Fischer, H. Schrader usw., Abh.d. Kohle, $1920,4,373 ; 1922,5 ， 415 ； 1923 ， 6 ， 128 ）$ は水素、望素、一酸化炭素、石炭瓦斯等と共にクレッ゙ール蒸氣を $700^{\circ}-800^{\circ} \mathrm{C}$ に加熱し多量のベン・゙ール、トルオール及少量の石炭酸及ナフタリン等を得たる事を報告せり近く はハーゲマン (A. Hagemann, Braunkohle，1929, 28, 1078, 1095) は各種の接觸劑を用るてメタクレッ゙ールの 熱分解を行ひベンゾール、ナフタリン、アンスラセン等の各溜分を得之等より其の分解機構を考察し丈中井利 三郎氏 (海軍燃料敵研究報告, 昭 4, 第 4 卷, 第 5 號; Bull. Chem. Soc. Japan.1930, 5, 136) はオルソ、メタ 及パラの各クレン゙ールを各種の接觸劑を滿たせる硝子管中に通し $600 \sim 700^{\circ} \mathrm{C}$ にて熱分解を行ひベンゾール、 石炭酸等を得之等の收率と分解各條件との關係を求め偷其の分解機構を考察せり

\section{實 驗 の 部}

本實驗に用るたる裝置及方法はベンジール乃至トルオールの熱分解の場合(本誌，昭 3，31，508; 昭 4, 32， 1006 參照）と全く同樣なり試料はカールバウム製純メタクレジールを蒸溜し $201 \pm 5^{\circ} \mathrm{C}$ の部分を探りて使用 せり 
分解によりて生成せる凝樎物、瓦斯 $\left(0^{\circ}, 760 \mathrm{~mm}\right)$ 及遊㒕炭素の各量を示せば次の如し(第一表) 但し之等 の數値は一條件の實驗 2 回乃至 5 包の平均を示す (以下各表とも同樣)

\begin{tabular}{|c|c|c|c|c|c|c|c|}
\hline \multirow{3}{*}{$\begin{array}{c}\text { 分解溫度 } \\
\left({ }^{\circ} \mathrm{C}\right)\end{array}$} & \multirow{3}{*}{ 接 觸 劑 } & \multirow{3}{*}{$\begin{array}{c}\text { 試 料 量 } \\
\text { (g) }\end{array}$} & \multirow{3}{*}{$\begin{array}{c}\text { 一 } \\
\text { 瓦斯發生量 } \\
\text { (cc) }\end{array}$} & \multicolumn{4}{|c|}{ 表 } \\
\hline & & & & 滪縮 & 忽量 & & 素量 \\
\hline & & & & $\widetilde{(g)}$ & $\overline{(\%)}$ & (g) & $(\%)$ \\
\hline 700 & 石 英 & 108 & 3840 & 102.57 & 94.97 & 0.73 & 0.68 \\
\hline 700 & 骵 宸 & " & 3335 & 103.65 & 95.97 & 0.45 & 0.42 \\
\hline 800 & 石 英 & "I & 27990 & 77.98 & 72.20 & 3.78 & 3.50 \\
\hline 800 & 骸 宸 & " & 32233 & 72.50 & 67.13 & 3.27 & 3.03 \\
\hline 900 & - & " & 51300 & 40.70 & 37.69 & 15.95 & 14.77 \\
\hline
\end{tabular}

上表に明なる如く分解溫度の上昇と共に瓦斯及炭素の生成量增大し凝縮物は減少す凝縮物は謟褐色液澧にし て分解溫度高き程黑色粘調性となる瓦斯分析の結果は第二表に示寸如く其の主成分は一酸化炭素、水素及×タ ンにして分解溫度の上昇と共にメタン量を減少し水素量を增大寸

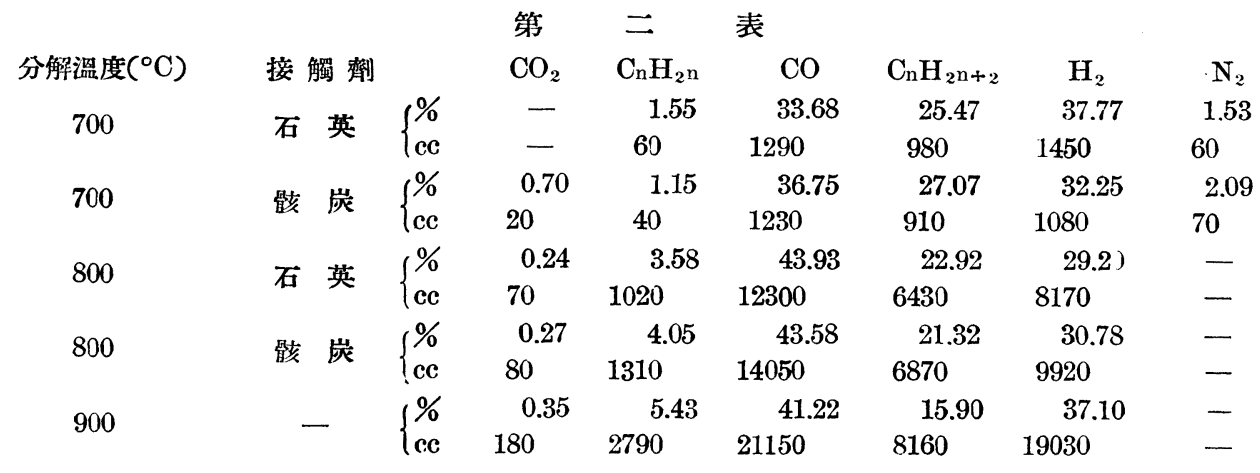

第一表各㠜縮物は之を蒸溜して數個の溜分に分ちたるが其の結果は第三表に示すが如し

$$
\text { 第 三 表 }
$$

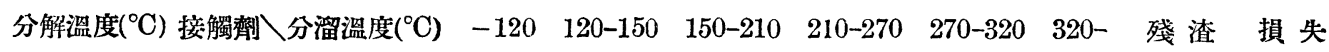
$700 \quad$ 石 英 $\left\{\begin{array}{lllllllll}\mathrm{g} & 2.50 & - & 91.43 & 1.37 & 1.53 & 1.40 & 2.77 & 1.57 \\ \% & 2.32 & - & 84.61 & 1.27 & 1.42 & 1.30 & 2.56 & 1.45 \\ \text { 性狀 } & \text { 淡黄液 } & \text { - } & \text { 淡黃液 } & \text { 暗綠液 } & \text { 暗綠液 } & \text { 暗赤褐液 } & & \end{array}\right.$ 性狀 淡黃液 - 淡黃液 暗綠液 暗綠液 暗赤褐液

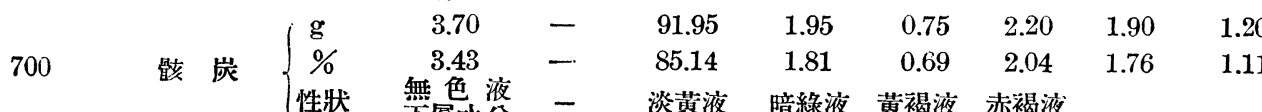
性狀無層水分 - 淡黃液 暗綠液 黃褐液 赤褐液

$800 \quad$ 石 英 $\left\{\begin{array}{ccccccccc}\mathbf{g} & 22.50 & 4.32 & 32.76 & 3.56 & 3.52 & 3.34 & 6.72 & 1.26 \\ \% & 20.90 & 4.00 & 30.33 & 3.30 & 3.26 & 3.09 & 6.22 & 1.17 \\ \text { 性狀 } & \text { 無 色液 } & \text { 淡黄液 } & \text { 暗褐液 } & \text { 黄褐液 } & \text { 赤褐液 } & \text { 暗赤褐液 } & & \end{array}\right.$

$800 \quad$ 駭 崖 $\left\{\begin{array}{lllllllll}\mathrm{g} & 25.70 & 3.83 & 24.17 & 4.47 & 3.93 & 2.87 & 6.30 & 1.23 \\ \% & 23.80 & 3.55 & 22.38 & 4.14 & 3.64 & 2.76 & 5.83 & 1.14 \\ & & \end{array}\right.$
性狀無色虚水分微黄液 淡带液 淡黄液 黄褐液 暗褐液

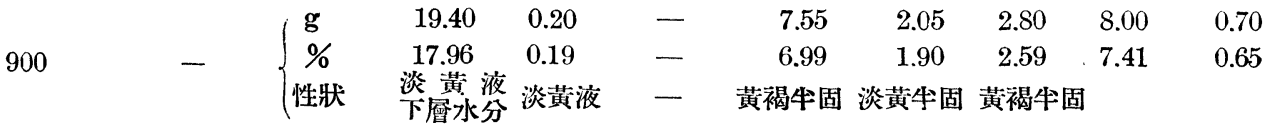

以上の分溜結果を見るに 分解温度 $700^{\circ} \mathrm{C}$ に於ては $150^{\circ}-210^{\circ} \mathrm{C}$ の溜分最も多く他の溜分は極めて僅少なり 又 $800^{\circ} \mathrm{C}$ の場合に於ては $150^{\circ}-210^{\circ} \mathrm{C}$ 及 $150^{\circ} \mathrm{C}$ 汽の溜分最も多く殘渣 $\left(370^{\circ} \mathrm{C}\right.$ 以上) 稍多し之に反し $900^{\circ} \mathrm{C}$ 
の場合は $150^{\circ} \mathrm{C}$ 迄の溜分獨り多く次に $210^{\circ}-270^{\circ} \mathrm{C}$ 及び殘渣稍多し

$150^{\circ} \mathrm{C}$ 以上の溜分は之を酸性分と中性分とを分つ鳳に苛性曹達液 (約 $10 \%$ ) 加へて振盪しェーテルにて抽 出し抽出液を留化カルシウムにて乾燥したる後エーテルを逐ひ出し其の抽出物量師ち中性分量を求め之と全量 との差より酸性分量を求めたり其の結果を示せば第四表の如し

第四表

\begin{tabular}{|c|c|c|c|c|c|c|c|c|}
\hline $\begin{array}{c}\text { 分解溫度 } \\
\left({ }^{\circ} \mathrm{C}\right)\end{array}$ & 接 觸 劑 & 成分】分溜溫度 $\left({ }^{\circ} \mathrm{C}\right)$ & $120-150$ & $150-210$ & $210-270$ & $270-320$ & 320 & 合 計 \\
\hline \multirow{4}{*}{700} & & \multirow{2}{*}{ 中 } & 一 & 1.13 & 0.20 & 0.83 & 0.83 & 3.00 \\
\hline & \multirow{3}{*}{ 石 } & & - & 1.05 & 0.19 & 0.77 & 0.77 & 2.78 \\
\hline & & \multirow{2}{*}{ 酸 $\left\{\begin{array}{l}\mathrm{g} \\
\%\end{array}\right.$} & - & 90.30 & 1.17 & 0.70 & 0.57 & 92.74 \\
\hline & & & - & 83.61 & 1.08 & 0.65 & 0.53 & 85.87 \\
\hline \multirow{4}{*}{700} & \multirow{4}{*}{ 娟 宸 } & & - & 1.30 & 0.30 & 0.55 & 1.10 & 3.25 \\
\hline & & & - & 1.20 & 0.28 & 0.51 & 1.02 & 3.00 \\
\hline & & & - & 90.65 & 1.65 & 0.20 & 1.10 & 93.60 \\
\hline & & & - & 83.94 & 1.53 & 0.19 & 1.02 & 86.67 \\
\hline \multirow{4}{*}{800} & \multirow{4}{*}{ 石 英 } & \multirow{2}{*}{ 中 $\left\{\begin{array}{l}\mathrm{g} \\
\%\end{array}\right.$} & 3.78 & 4.76 & 2.18 & 3.06 & 2.54 & 16.32 \\
\hline & & & 3.50 & 4.41 & 2.02 & 2.83 & 2.35 & 15.11 \\
\hline & & \multirow{2}{*}{ 酸 $\left\{\begin{array}{l}0 \\
\%\end{array}\right.$} & 0.54 & 28.00 & 1.38 & 0.46 & 0.80 & 31.18 \\
\hline & & & 0.50 & 25.93 & 1.28 & 0.43 & 0.74 & 28.88 \\
\hline \multirow{4}{*}{800} & \multirow{4}{*}{ 敂 宸 } & \multirow{2}{*}{ 中 $\left\{\begin{array}{l}g \\
\%\end{array}\right.$} & 3.13 & 4.33 & 2.30 & 3.43 & 2.33 & 15.53 \\
\hline & & & 2.90 & 4.00 & 2.13 & 3.18 & 2.16 & 14.38 \\
\hline & & & 0.70 & 19.83 & 2.17 & 0.50 & 0.53 & 23.73 \\
\hline & & $1 \%$ & 0.65 & 18.36 & 2.01 & 0.46 & 0.49 & 21.97 \\
\hline \multirow{4}{*}{900} & \multirow{4}{*}{ - } & $\{\mathbf{g}$ & 0.20 & - & 7.20 & 1.85 & 2.60 & 11.85 \\
\hline & & $1 \%$ & 0.19 & 一 & 6.66 & 1.71 & 2.41 & 10.97 \\
\hline & & & - & - & 0.35 & 0.20 & 0.20 & 0.75 \\
\hline & & $\{\%$ & - & - & 0.32 & 0.19 & 0.19 & 0.69 \\
\hline
\end{tabular}

(上表中、中は中性分、酸は酸性分か示す)

中性分を抽出したる後のアルカリ溶液はをを硫酸にて酸性としエーテルにて抽出し抽出液を監化カルシウム にて乾燥したる後ェーテルを逐ひ出して酸性分を包收し之を蒸溜して其の約 $200^{\circ} \mathrm{C}$ 汽の溜分より結水點測定 法によりて其の中の 石炭酸量を求め (Dawson \& Mountford, J. Chem. Soc., 1918, 928 參照) 之と全酸性分 量との差を以て不分解クレゾールとし之を上表計算上の酸性分の數值に換算して得たる平均は次の如し（第五 表）酸性分の蒸溜結果及び結氷的測定結果は省略せり

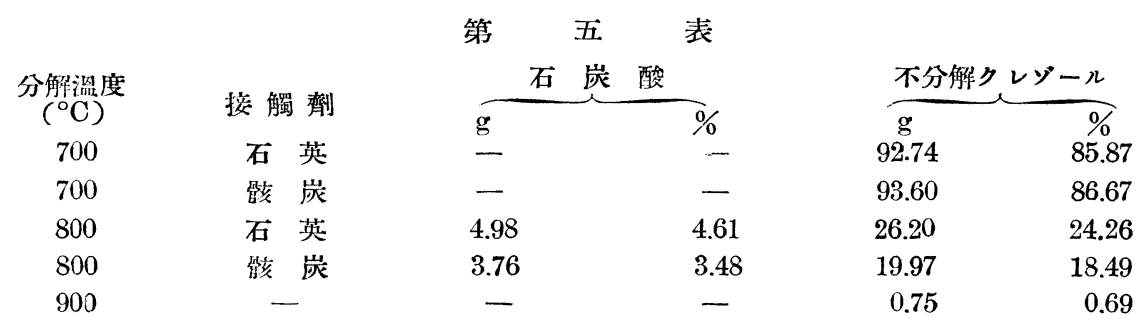

此の結果より見るに $700^{\circ} \mathrm{C}$ に於ては殆んど石炭酸の生成を認めず又 $900^{\circ} \mathrm{C}$ に於ては生成石炭酸は殆んど完

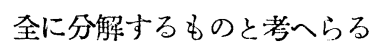

第二表中 $120^{\circ} \mathrm{C}$ 迄の溜分は分別漏斗中に静置して水分と油分とを分ち其の量を科りたる後油分は之を精溜 管を附して蒸溜し $111^{\circ} \mathrm{C}$ 迄の溜分を採り監化カルシウムにて充分乾燥したる後トルオールの熱分解の場合と 同樣著者の考案せる方法により其の中のベンゾール量を求め之と全量との 美及び第四表 $120^{\circ}-150^{\circ} \mathrm{C}$ の溜分 
中の中性分との和を以てトルオール量とせり（本誌, 昭 4, 32,943 參照) 斯くして 得たる水分、ベンジール 及びトルオールの各本均值は第六表に示すが如し

\begin{tabular}{|c|c|c|c|c|c|c|c|}
\hline \multirow{3}{*}{$\begin{array}{c}\text { 分解溫度 } \\
\left({ }^{\circ} \mathrm{C}\right)\end{array}$} & \multirow{3}{*}{ 接 觸 劑 } & \multicolumn{2}{|c|}{ 第 } & \multicolumn{2}{|l|}{ 表 } & & \\
\hline & & \multicolumn{2}{|c|}{ 水 } & \multicolumn{2}{|c|}{ ペンゾール } & \multicolumn{2}{|c|}{ トルオール } \\
\hline & & $g$ & $\%$ & $\mathrm{~g}$ & $\%$ & $\mathrm{~g}$ & $\%$ \\
\hline 700 & 石 英 & 0.17 & 0.16 & 1.46 & 1.35 & 0.87 & 0.81 \\
\hline 700 & 骸 孷 & 1.55 & 1.44 & 1.32 & 1.22 & 0.83 & 0.78 \\
\hline 800 & 石 英 & 1.62 & 1.51 & 15.36 & 14.23 & 9.30 & 8.69 \\
\hline 800 & 骸 孷 & 1.90 & 1.78 & 18.30 & 16.94 & 8.53 & 7.97 \\
\hline 900 & - & 1.45 & 1.36 & 15.90 & 14.72 & 2.25 & 2.10 \\
\hline
\end{tabular}

第四表 $150^{\circ} \mathrm{C}$ 以上の中性溜分は褐色乃至晤褐色油にして中に 黃色結晶性固體を含むものあり之よりピクレ 一トを生成する成分と然らざるものとを分つ䉆に石炭酸乃至トルオールの熱分解生成物に試みたると同樣の方 法を採用せり郎ち試料少き故同溫度の溜分を合し之を無水酒精に溶し過剩のピクリン酸を加へて溫め低溫に於 て酒精を完全に逐ひ出したる後石油エーテルを以て殘渣を抽出し抽出液は水にて洗策し盤化カルシウムにて充 分乾燥したる後石油エーテルを逐ひ出してピクレートを生成せざる部分を包收し抽出残渣は蒸氣蒸溜により又 はアルカリに溶したる後ベンジールにて抽出して其の中のピクレート生成物を囸收せり斯くして得たる各溜分 中の本均各量は次の如し

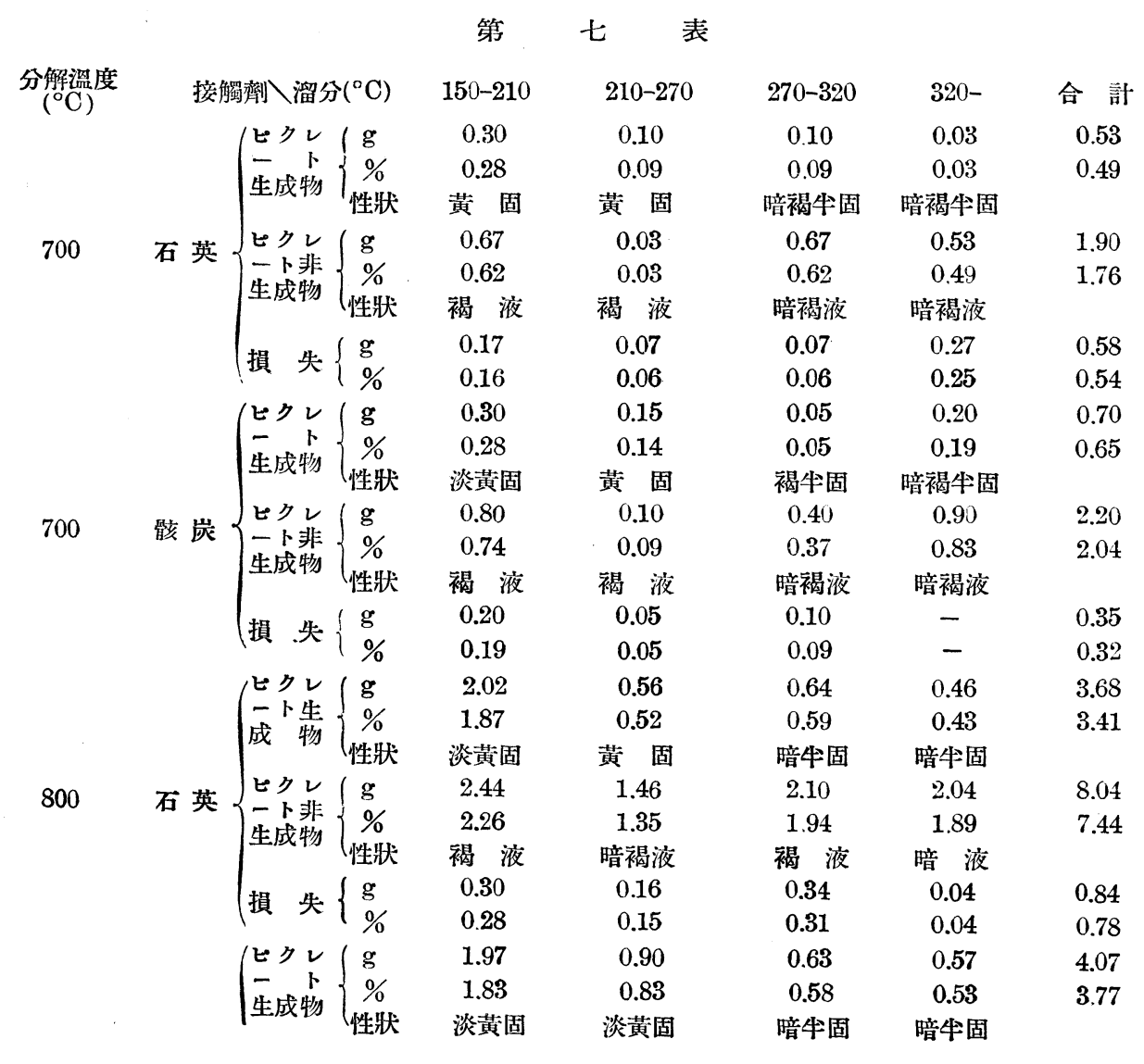




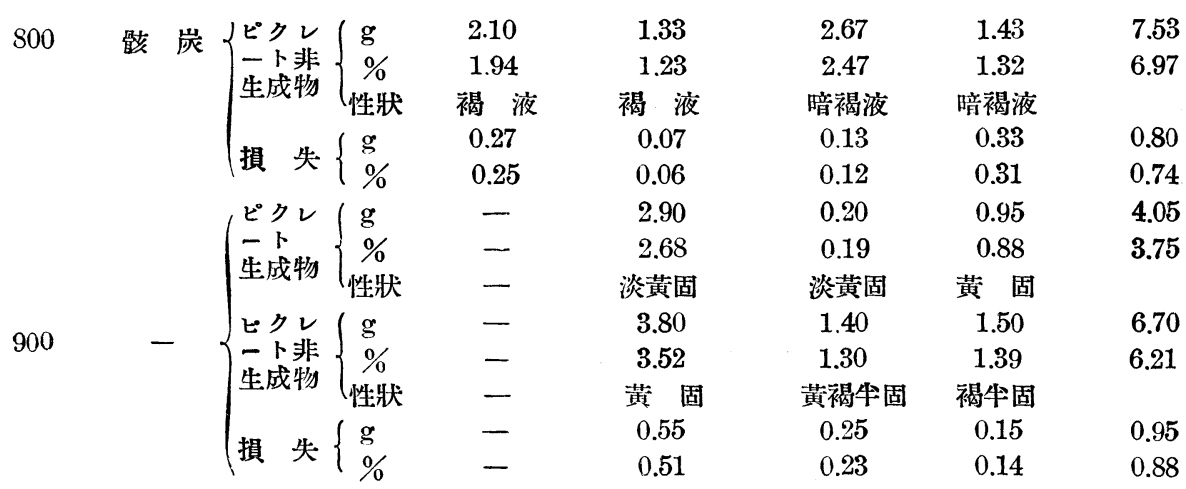

ピクレート生成物中 $800^{\circ} \mathrm{C}$ 及 $900^{\circ} \mathrm{C}$ に相當寸るものは之を全部集めて更に分溜せり其の際得た各溜分の割 合及び性狀は次の如し

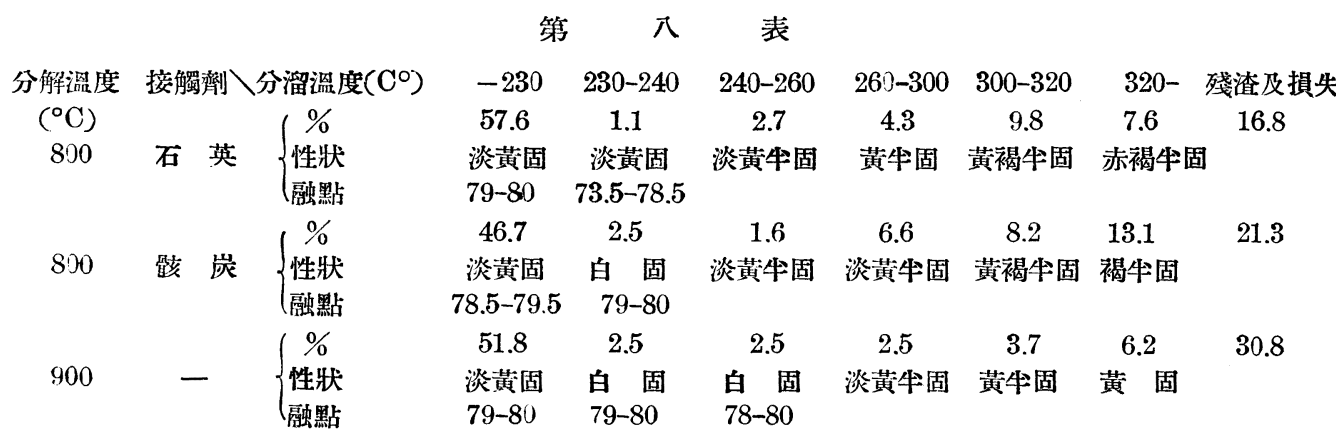

郎ちピクレート生成物は主として $230^{\circ} \mathrm{C}$ 迄の溜分及 $300^{\circ} \mathrm{C}$ 以上の溜分に多し $230^{\circ} \mathrm{C}$ 迄の溜分は其の性狀、 融點及其のピ クレートの性狀並に融點等よりナフタリンなる事を確かめたり $300^{\circ} \mathrm{C}$ 以上の溜分は之をべンッ゙ ールより再結晶する事によりて $900^{\circ} \mathrm{C}$ に相當するものよりはアンスラセンを分離する事を得たり $800^{\circ} \mathrm{C} に$ 相 當するものよりは高融熙淡黄結晶を得たるも其の量少くして其の成分を確定するに至らざりしも既往の研究に 徵し之等の溜分はアンスラセン、フェナンスレン乃至其の同族艠等より成るべきは察するに難からずヌ $700^{\circ} \mathrm{C}$ に相當するもの $233^{\circ} \mathrm{C}$ 迄の溜分は之を酒精より再結晶する事によりナフタリンを檢出するを得たり $250-300^{\circ}$ の溜分は何れの場合にも牛固狀を呈出するもの多く之より純粹なる成分を檢出するを得ざりしも其の性狀及び ピクレートの性狀等より察するにナフタリン及び其の同族體、フェナンスレン等が混在するものなるべし

第七表ピクレートを生成せざる物の中 $90^{\circ} \mathrm{C}$ に相當するものは固體乃至牛固體にして此の中 $270^{\circ} \mathrm{C}$ 迄の溜

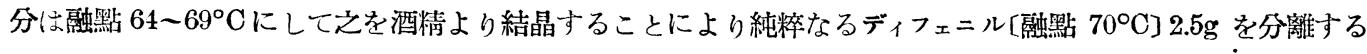
事を得たり $270^{\circ} \mathrm{C}$ 以上の溜分よりは純粹なる成分を稀定するを得ざりしも其の元素分析結果より各種ディフェ ニルベンゾール乃至其の同族體なるべしと考へらる

分解溫度 $700^{\circ} \mathrm{C}$ 及 $800^{\circ} \mathrm{C}$ に相當するものは何れも液狀をなすを以て之等を合して再分溜せり其の結果得た る各溜分の得量(\%)及性狀は次の如し

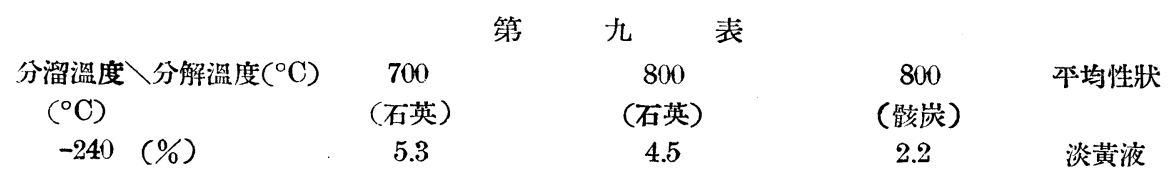




$\begin{array}{llrrr}240-250 \text { " } & 22.8 & 10.4 & 9.3 & \text { 淡黃液 } \\ 250-260 \text { " } & 19.3 & 9.7 & 8.4 & \text { " } \\ 260-270 \text { " } & 26.3 & 9.5 & 12.8 & \text { 黃褐液 } \\ 270-280 \text { " } & - & 9.5 & 9.7 & \text { " } \\ 280-290 \text { " } & - & 9.5 & 9.7 & \text { " } \\ 290-300 \text { " } & - & 9.7 & 5.8 & \text { " } \\ 300-320 \text { " } & - & 11.9 & 10.2 & \text { 革褐牛固 } \\ 320- & - & 11.5 & 14.2 & \text { " } \\ \text { 殘渣及損失" } & 26.3 & 13.9 & 17.7 & 100.0\end{array}$

之等の溜分の數種に就きて元素分析を行ひたる結果は次表（第一○表）の如く何れも多少の酸素化合物を含 むを知る之等酸素化合物の何たるかは之を明にせざりしも其の 性狀及從來の 交骿に徵し恐らくディフェニルェ 一テル乃至其の同族體なるべく從つて各溜分は之等とディフェニル、ディフェニルベンジール乃至其等の同族體 とが混合せるものなるべし

\begin{tabular}{|c|c|c|c|c|c|c|c|c|c|}
\hline 分 ${ }^{\left({ }^{\circ} \mathrm{C}\right)}$ & & $00(\%)$ & & & $\begin{array}{l}800(\%) \\
\text { (石英 }\end{array}$ & & & 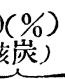 & \\
\hline C) $\backslash$ & $\mathrm{C}$ & $\mathrm{H}$ & O & $\mathrm{C}$ & $\mathrm{H}$ & $\mathrm{O}$ & $\mathrm{C}$ & $\mathrm{H}$ & $\mathrm{O}$ \\
\hline $240-250$ & & & & & & & 91.15 & 6.67 & 2.18 \\
\hline $250-260$ & 87.27 & 6.78 & 5.95 & 90.83 & 6.56 & 2.61 & & & \\
\hline $260-270$ & 86.45 & 6.52 & 7.13 & & & & 90.23 & 6.38 & 3.39 \\
\hline $\begin{array}{l}270-280 \\
280-290\end{array}$ & & & & $\begin{array}{l}89.87 \\
90.02\end{array}$ & $\begin{array}{l}6.26 \\
6.33\end{array}$ & $\begin{array}{l}4.87 \\
3.65\end{array}$ & 89.89 & 6.28 & 3.83 \\
\hline 290-300 & & & & & & & 89.65 & 6.33 & 4.02 \\
\hline $300-320$ & & & & 91.83 & 6.12 & 2.05 & & & \\
\hline 320 & & & & 91.05 & 6.41 & 2.54 & & & \\
\hline
\end{tabular}

郎ち酸素化合物は $700^{\circ} \mathrm{C}$ に相當するものに多く而して $900^{\circ} \mathrm{C}$ に相當するもの存在せず郎ちディフェニルェ ーテル類は溫度の增大と共に減少するものっ如し

以上の結果より今第七表に於てピクレート生成物中 $270^{\circ} \mathrm{C}$ 迄の溜分を總てナフタリン及び其の同族體とし $270^{\circ} \mathrm{C}$ 以上の溜分をアンスラセン、フェナンスレン乃至之等の同族體としビクレート非生成物及損失は之を ディフェニル類及びディフェニルェーテル類とすればメタクレッ゙ール $1 \mathrm{~g}$ 分子の熱分解によりて生成せる各成分 の得量は第一一表に示寸が如し

\begin{tabular}{|c|c|c|c|c|c|c|c|}
\hline \multirow{2}{*}{$\begin{array}{l}\text { 分解溫度 } \\
\left({ }^{\circ} \mathrm{C}\right)\end{array}$} & \multirow[t]{2}{*}{ 接 觸 劑 } & \multicolumn{2}{|c|}{ ナフタリン類 } & \multicolumn{2}{|c|}{ 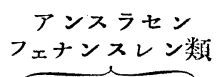 } & \multicolumn{2}{|c|}{$\begin{array}{c}\text { ディフェニル類 } \\
\text { ディフェニルェーデ 類 }\end{array}$} \\
\hline & & $\mathrm{g}$ & $\%$ & g & $\%$ & $\mathrm{~g}$ & $\%$ \\
\hline 700 & 石 英 & 0.40 & 0.37 & 0.13 & 0.12 & 2.48 & 2.30 \\
\hline 700 & 駭 炭 & 0.45 & 0.42 & 0.25 & 0.23 & 2.55 & 2.36 \\
\hline 800 & 石 英 & 2.58 & 2.38 & 1.10 . & 1.02 & 8.88 & 8.22 \\
\hline 800 & 䯓 宸 & 2.87 & 2.66 & 1.20 & 1.11 & 8.33 & 7.71 \\
\hline 900 & - & 2.90 & 2.68 & 1.15 & 1.06 & 7.65 & 7.09 \\
\hline
\end{tabular}

以上の結果を通觀するにメタクレゾールの分解は $800^{\circ} \mathrm{C}$ 附近より急激に盛となり $960^{\circ} \mathrm{C} に$ 於ては㱠んど完 全なり分解による生成物は主としてベンジール、トルオール、石炭酸等なるが之等は分解溫度の上昇と共に一 度增大寸るも再び減退し特に石炭酸は $900^{\circ} \mathrm{C}$ に於ては殆儿ど之を認めずナフタリン、アンスラセン等ピクレ 一ト生成物は比較的少く且つ分解溫度の差による變化少くこディフェニル類は分解溫度の上梨と共に㒄大しディ 
フェニルェーテル類は比較的低溫に於て生成盛なるも溫度の上昇と共に減退するが如し

接觸劑の影響を見るに $700^{\circ} \mathrm{C}$ に於ては殆んど其の差を認め難く $800^{\circ} \mathrm{C}$ に於て骸炭の場合は石英に比し分解 クレッ゙ール量及ベンゾール生成量多く石炭酸及びトルオール生成量稍少し之果して接觸齌の機能の差によるも のなるや或は實驗の誤差に因るものなるや判明せず然れども既往の㸴究に徵するに之等接觸劑の影響は殆んど 認められざるを以て此の程度の誤差は後者に歸因するものと解して可なるべし

結 論

石英硝子粒及鲑炭粒を接觸劑として $700^{\circ} \mathrm{C}$ 及 $800^{\circ} \mathrm{C}$ に於て又何れの接觸璾をも用ひずして $900^{\circ} \mathrm{C}$ に於て 純メタクレゾールの熱分解を行ひたる結果次の事を明にするを得たり

1. 接觸劑の影響は殆んど無きか又は極めて僅少なり

2. $700^{\circ} \mathrm{C}$ に於ては試料の $13-14 \% 、 800^{\circ} \mathrm{C}$ に於て $75-85 \% 、 900^{\circ} \mathrm{C}$ に於ては殆んど完全に分解寸

3 分解によりて生成するものはベンジール、トルォール、石炭酸、ナフタリン類、アンスラセン、フェナ ンスレン類、ディフェニル類、ディフェニル、エーテル類等にしてベンヅール、トルオール、石炭酸は分解溫度に 對しある極大值を有し石炭酸は $700^{\circ} \mathrm{C}$ 及 $900^{\circ} \mathrm{C}$ に於ては殆んど生成せずナフタリン類、アンスラセン類等ピ クレート生成物は分解溫度の差による變化比較的少くディフェニル類は分解溫度の上昇と共に增大しディフェニ ルェーテル類は之に反す

4. 生成瓦斯量及び遊離炭素は分解溫度と共に增大し前者は主として一酸化炭素、水素及びメタンよりなり 分解溫度の上昇と共に水素の割合增大寸

本研究に關し御想篤なる御敎示名賜りたる大島教授に深謝の意か表す

（東京帝國大學工學部應用化學科研究室）（昭和五年一一月八日受理）

\section{コールタール成分の熱分解に關する研究(第八報) オルソ及ハラクレリ゙ールの熟分解反應生成物}

香 坂 要 三 郎

本實驗に使用せる装置及方法はメタクレッ゙ールの場合(本誌, 昭 $6,34,17$ ) と全く同樣なり但し本實驗に於て は $800^{\circ} \mathrm{C}$ に於て石英硝子粒を接觸劑とせる場合に就ての久行ひたり試料は何れもカールバウム製純クレジール にして之を再び蒸溜しオルックレッ゙ールは $193 \pm 5^{\circ} \mathrm{C}$ パラクレッ゙ールは $200 \pm 55^{\circ} \mathrm{C}$ の部分を探りて使用せり 尙以下示寸處の各數值は同條件の實驗 3 四の平均にして又比較の 舄同條件にて行へるメタクレジールの結 果 (前報告參照) をも併記せり

分解によりて生成せる凝縮物、瓦斯及遊離炭素の各量 (第一表)、瓦斯分析結果 (第二表)、凝縮物分溜結果 (第三表)、㠜縮物中の酸性分及び中性分量(第四表)を示せば次の如し

\section{第一 表 (分解生成物各量)}

\begin{tabular}{|c|c|c|c|c|c|c|c|c|}
\hline \multirow[t]{2}{*}{$\Rightarrow 2$} & \multirow{2}{*}{ ゾー } & \multirow[t]{2}{*}{ ル } & \multirow{2}{*}{$\begin{array}{c}\text { 試 料 量 } \\
(\mathrm{g})\end{array}$} & \multirow{2}{*}{$\begin{array}{c}\text { 瓦斯發生量 } \\
\text { (cc) }\end{array}$} & \multicolumn{2}{|c|}{ 凝縮物總量 } & \multicolumn{2}{|c|}{ 遊離炭素 } \\
\hline & & & & & (g) & $(\%)$ & $\widetilde{(g)}$ & $(\%)$ \\
\hline オ & u & \% & 108.0 & 26100 & 80.60 & 74.63 & 4.33 & 4.01 \\
\hline ハீ & & ラ & "I & 28800 & 75.97 & 70.34 & 4.80 & 4.44 \\
\hline$x$ & & タ & " & 27990 & 77.98 & 72.20 & 3.78 & 3.50 \\
\hline
\end{tabular}

